\title{
Grapes (Vitis Vitaceae) - Potent Medicinal Fruit Serves as a Source of Antioxidants and Antibacterial Agent
}

\author{
Mr. G. Karthikeyan ${ }^{1}$, Ms. V. G. Lavanya ${ }^{2}$, Ms. N. Dharani ${ }^{3}$, Mr. T. G. Nagulan ${ }^{4}$ \\ ${ }^{1}$ Assistant Professor, Department of Biochemistry, Kongu Arts and Science College (Autonomous), Erode \\ ${ }^{2,3 \& 4}$ II - M.Sc Biochemistry, Kongu Arts and Science College (Autonomous), Erode
}

\begin{abstract}
In plant kingdom, medicinal plants are main important resource for a variety of drug like emetics, anti-cancer and antimicrobials. Medicinal herbs are highly cultured in India, which includes more than 2000 species are present. Grapes are soft fruit crop belongs to the Family of Vitaceae and Genus of Vitis. Grapes contain excellent source of nutritional values such as vitamins, minerals, proteins and carbohydrate. In this present work, various phytochemical constituents of grapes were identified in different extracts (Ethanol, Acetone and Aqueous). These phytochemicals are used for the treatment of several diseases. The antioxidant property of different extracts of grapes shows better result. The ellagic acid and the natural phenolic antioxidants were also identified. The antimicrobial activity of various grapes extract shows better result against Enterococcus and E.coli sps. Finally, the grape fruit is a wonderful antioxidant and antimicrobial agent.
\end{abstract}

KEY WORDS: Antibacterial, Ellagic acid, phytochemicals, Antioxidants.

\section{INTRODUCTION}

India has a rich culture of medicinal herbs and spices which includes about more than 2000 species and has a vast geographical area with high potential abilities for Ayurveda, Siddha traditional medicines [2]. But only very few have been studied chemically and pharmacologically for their potential medicinal value. Medicinal plants are important with respect to new drug and pharmacological research development. These medicinal plants are used in the treatment of many infectious diseases. Researchers are turning their attention to natural products to develop better anticancer, antiviral and antibacterial drugs. The antimicrobial properties of medicinal plants are being increasingly reported from different parts of the world [10,2]. In this study traditional human uses of plants, is recognized as an effective way to discover further medicines. From the recent researches, 122 compounds are identified and derived from traditional plants sources which are used in modern medicine. All parts in a plant possess the medicinal values such as leaf, stem, fruits, buds, roots, etc [5]. Now we are ready to use the grape fruits (vitis vinifera) as medicinal herbs because it was consumed either as fruit or juice by every individual day by day without knowing their medicinal values. Grapes are considered to be a berry. In the wild species it is $6 \mathrm{~mm}(0.24)$ diameter and ripens dark purple to blackish with a pale wax bloom. The wild grape is classified as vitis vinifera sub species. Ayurveda has been recognized the medicinal value of grape. Common name: Grape; Type: Tree; Height: 115feet; Water: Medium; Fruit: Edible; Kingdom: Plantae; Order: Vitales; Binomial name: Vitis vinifer [15].

Grapes are good source of vitamin C and K. They also contain protein, carbohydrates, dietary fiber and minerals [6]. Grape is a one of the most popular fruit and contain large amount of phytochemicals such as phenolic acid, flavonoids, tannins, anthocyannins, cyanidin, ellagic acid, proanthocyanidins which offer health benefits [8]. The anthocyanin present is responsible for the different colours of grape fruit like black, red and purple. Different parts of the plants could be used for a fever, diarrhea and ulcer [7]. The grape fruits must have antioxidant capacity used to treat many various rare diseases. It also serves as an antimicrobial agent because they have many secondary metabolites [11]. The aim of the work is to study the phytochemical analysis in different extracts of grapes (fruit) and to study its effect as anti-oxidant and antimicrobial activities.

\section{MATERIALS AND METHODS}

\subsection{Collection and Extraction of the grape fruit}

The fruit of Vitis vinifera was collected from erode local market, Tamil Nadu. The fresh plant material is extracted using soxhlet assembly and successively with ethanol, acetone and distilled water. Finally the plant material is macerated with distilled water. The extracted material is concentrated by evaporation. 


\section{International Journal of Current Science Research and Review}

ISSN: 2581-8341

Volume 03 Issue 08 August 2020

DOI: 10.47191/ijcsrr/V3-i08-02, Impact Factor: 6.595

IJCSRR@ 2020

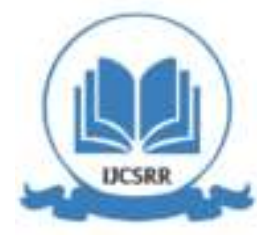

WWw.ijcsrr.org

\subsection{Experimental profile}

\subsubsection{Ethanol extract of Vitis vinifera}

About $50 \mathrm{gm}$ of fresh fruit was extracted with $250 \mathrm{ml}$ of ethanol by continuous hot percolation using soxhlet apparatus. After completion of extraction, it was filtered and concentrated to fresh mass by vacuum distillation. A dark pink and light yellow colour and waxy residue was obtained. The extract was the stored in a desiccator.

\subsubsection{Acetone extract of Vitis vinifera}

The marc left after ethanol extract was dried and subsequently extracted with $250 \mathrm{ml}$ of acetone by continuous hot percolation using soxhlet apparatus. After completion of extraction, it was filtered and the solvent was removed by distillation under reduced pressure. A light yellow colour and waxy residue was obtained. The extract was the stored in a desiccator.

\subsubsection{Aqueous extract of Vitis vinifera}

The marc left after acetone extraction was taken and finally macerated with $250 \mathrm{ml}$ of distilled water in a narrow mouthed bottle for 3 days. After completion of extraction, it was filtered and the solvent was removed by distillation under reduced pressure. A light pink colour and waxy residue was obtained. The extract was the stored in a desiccator.

All these extracts were used for the identification of active constituents by following tests.

\subsection{Preliminary studies of Vitis vinifera fruit extract}

\subsubsection{ALKALOIDS}

a) Mayer's test: To a few $\mathrm{ml}$ of filtrate, two drops of Mayer's reagent was added along with the sides of the test tube. If the test is positive, it gives white or creamy precipitate indicates the presence of alkaloids.

b) Wagner's test: To a few $\mathrm{ml}$ of the filtrate, few drops of Wagner's reagent were added along with the sides of the test tube. Formation of reddish brown precipitate indicates test as positive.

c) Dragendroff's test: To a few $\mathrm{ml}$ of filtrate, 1 or $2 \mathrm{ml}$ of Dragendorff's reagent was added. A prominent reddish brown precipitate indicates positive test.

2.3.2. AMINO ACIDS: The extract is dissolve in $10 \mathrm{ml}$ of distilled water and filtered through Whatmann filter paper 1.0 and the filtrate was subjected to test for amino acids.

a) Ninhydrin test: Two drop of Ninhydrin solution is added to $2 \mathrm{ml}$ of aqueous filtrate. Appearance of purple colour indicates the presence of amino acids.

\subsubsection{CARBOHYDRATES}

a) Molish's test: To $2 \mathrm{ml}$ of filtrate, two drops of alcoholic solution of 1 - Napthol was added. The mixture was shaken well and $1 \mathrm{ml}$ of concentrated Sulphuric acid was added slowly along the sides of the test tube, the test tube was cooled in ice water and allowed to stand. A violet ring at the junction of two liquids indicates the presence of carbohydrates.

b) Benedict's test: To $0.5 \mathrm{ml}$ of filtrate, $0.5 \mathrm{ml}$ of Benedict's reagent was added. The mixture was heated on a boiling water bath for 2 minutes. A characteristic colored precipitate indicates the presence of sugar.

\subsubsection{OILS AND FATS}

a) Spot test: A small quantity of extract is pressed between the two filter papers. Oils stain on the paper indicates the presence of fixed oils.

b) Saponification test: A few drops of $0.5 \mathrm{~N}$ alcoholic potassium hydroxide solution is added to a small quantity of extract along with a drop of phenolphthalein. The mixer is heated on a water bath for 2hours formation of soap or partial neutralization of alkali indicates the presence of fixed oils and fats.

\subsubsection{PHENOLIC COMPOUNDS AND TANNINS}

a) Ferric chloride test: About $50 \mathrm{mg}$ of extract was dissolved in distilled water and to this few drops of neutral $5 \%$ ferric chloride solution was added. Formation of blue, green and violet color indicates the presence of phenolic compounds.

b) Lead acetate test: A small quantity of extract was dissolved in distilled water and to this; $3 \mathrm{ml}$ of $10 \%$ lead acetate solution was added. A bulky white precipitate indicates the presence of phenolic compounds. 


\section{International Journal of Current Science Research and Review}

ISSN: 2581-8341

Volume 03 Issue 08 August 2020

DOI: 10.47191/ijcsrr/V3-i08-02, Impact Factor: 6.595

IJCSRR@ 2020

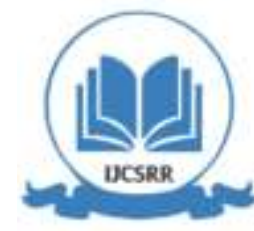

www.ijcsrr.org

\subsubsection{PHYTOSTEROLS AND TRITERPENOIDS}

a) Libermann - burchard's test: The extract was dissolved in acetic anhydride, heated to boiling, cooled and then $1 \mathrm{ml}$ of concentrated sulphuric acid was added along the side of the test tube. Red, pink or violet color at the junction of the liquids indicates the presence of steroids / triterpenoids and their glycosides.

2.3.7. PROTEIN: The extract is dissolve in $10 \mathrm{ml}$ of distilled water and filtered through Whatmann filter paper 1.0 and the filtrate was subjected to test for protein.

a) Millon's test: To $2 \mathrm{ml}$ of filtrate few drops of Millon's reagent are added. A white precipitate indicates the presence of proteins. b) Biuret test: $2 \mathrm{ml}$ of filtrate is treated with 1 drop of $2 \%$ copper sulphate solution. To this $1 \mathrm{ml}$ of ethanol is added, followed by excess of potassium hydroxide pellets Pink colour layer indicates the presence of proteins.

\subsubsection{SAPONINS}

a) Foam or Froth test: A small quantity of the extract was diluted with distilled water to $20 \mathrm{ml}$. The suspension was shaken in a graduated cylinder for 15 minutes. A two centimeter layer of foam or froth which is stable for 10 minutes indicates the presence of saponins.

\subsection{Estimation of Ash Content and Moisture Content}

2.4.1. Estimation of Ash content: Empty silica crucial was cleaned well and heated over a Bunsen flame to red hot. Cooled in a desiccator and weighed. Heating, cooling and weighing were repeated to obtain constant weight. About 4.0g of sample was taken in two different crucibles. The crucibles were heated over a Bunsen burner until the sample turned ash. Heating, cooling and weighing were repeated until constant weight were got.

2.4.2. Estimation of Moisture content: An empty crucible was cleaned well and heated to red hot over a bunsen burner. Cooled it in a desiccator and weighed. Heating, cooling and weighing were repeated until a constant weight was obtained. $4.0 \mathrm{~g}$ of sample was taken and heated in an oven at $100^{\circ} \mathrm{c}$ for $6 \mathrm{hrs}$. Cooled in adesiccators and again weighed. This procedure was repeated until constant weight was obtained.

\subsection{Test for biochemical components}

\subsubsection{Estimation of protein (Lowry's et al 1951)}

In a series of test tubes, pipette out $0.2 \mathrm{ml}$ to $1.0 \mathrm{ml}$ of the working standard BSA solution corresponding to $20 \mu \mathrm{g}$ to 200 $\mu \mathrm{g}$ values. Then take 1.0 and $2.0 \mathrm{ml}$ of the extracts in another two test tubes. Make up the volumes to $1 \mathrm{ml}$ in all test tubes. A tube with $1 \mathrm{ml}$ of water serves as the blank. Add $5 \mathrm{ml}$ of alkaline copper reagent to each tube including the blank. Mix well and incubate at room temperature in the dark for 30 mins. The blue colour developed was read at $660 \mathrm{~nm}$ in UV-Visible Spectrophotometer.

\subsubsection{Estimation of phosphorous (Fiske subbarow's method)}

In a series of test tubes, pipette out $0.2 \mathrm{ml}$ to $1.0 \mathrm{ml}$ of the working standard solution corresponding to $1.6 \mu \mathrm{g}$ to $8.0 \mu \mathrm{g}$ values. Then take 1.0 and $2.0 \mathrm{ml}$ of the extracts in another two test tubes. The volume of all the test tubes is made up to $9 \mathrm{ml}$ with distilled water. $9 \mathrm{ml}$ of distilled water is taken in a blank. $1 \mathrm{ml}$ of Ammonium Molybdate and $0.4 \mathrm{ml}$ of ANSA was added to all the test tubes. Mixed well and incubate at room temperature at 10 minutes. The blue colour developed was read at $680 \mathrm{~nm}$.

\subsubsection{Estimation of magnesium (Titan yellow method)}

In a series of test tubes, pipette out $0.2 \mathrm{ml}$ to $1.0 \mathrm{ml}$ of the working standard magnesium solution corresponding to $10 \mu \mathrm{g}$ to $50 \mu \mathrm{g}$ values. Then take 1.0 and $2.0 \mathrm{ml}$ of the extracts in another two test tubes. The volume of all the test tubes is made up to 3 $\mathrm{ml}$ with distilled water. $3 \mathrm{ml}$ of distilled water is taken in a blank. $1 \mathrm{ml}$ titan yellow and $1 \mathrm{ml}$ of NAOH was added to all the test tubes. The red colour was developed immediately read at $540 \mathrm{~nm}$.

\subsubsection{Separation of amino acids by Ascending paper chromatography}

The chromatography paper is cut carefully to convenient size $(40 \times 24 \mathrm{~cm})$. Draw a line with pencil across the sheet about $5 \mathrm{~cm}$ away from one end. Marked a number of points at travel of $3 \mathrm{~cm}$, applied a small volume $(25 \mu \mathrm{l})$ of each amino acid as a separate small spot using a capillary tube. Stream of hot air from a hair dryer facilitates fast drying of spot. The spot should be as small as possible for better resolution.

Similarly spot unknown (Vitisvenifera fruit sample) mixture of amino acids. After spotting the paper was folded in the form of cylinder and lengthwise edges were stitched together. The paper was placed upright with the spots at the bottom in a large petridish and closed the chamber airtight. Care was taken to see the paper and as the solvent ascends the amino acids travel with 


\section{International Journal of Current Science Research and Review}

ISSN: 2581-8341

Volume 03 Issue 08 August 2020

DOI: 10.47191/ijcsrr/V3-i08-02, Impact Factor: 6.595

IJCSRR@ 2020

www.ijcsrr.org

different mobility. Note the solvent front and dry the chromatogram free of solvent at room temperature by hanging with clips with the starting end downward. Spray the chromatogram with the Ninhydrin reagent and dry the paper for about $5 \mathrm{~min}$ at room temperature followed by $100^{\circ} \mathrm{C}$. Similarly spot unknown mixture of amino acids. After spotting, the paper placed in an oven for 23 minutes. Amino acids appear as purple spots, hydroxyl proline and proline gives yellow colored spots. The amino acids present in the unknown mixture are then mixed and then identified by comparing the Rf values with that of authentic amino acids, cochromatographed.

\subsection{Antibacterial activity (bewer et al 1966)}

At $45^{\circ} \mathrm{c}, 20 \mathrm{ml}$ of sterilized culture media is poured into the petri plates. After the agar is solidified, the testing organisms $(100 \mu \mathrm{l})$ are spread over it therough swab method. The test organisms are the Staphylococcus aurous, E. coli and pseudomonas species. Then add the different extracts $(100 \mu \mathrm{l})$ to the respective wells in the petriplate. These petriplates are incubated at $37^{\circ} \mathrm{C}$ for 24 hours at inverted position. After the incubation period, the zone of inhibition was determined. The result was obtained by measuring the zone in $\mathrm{mm} /$ diameter.

\subsection{Total antioxidant capacity}

In a series of test tubes, pipette out $0.2 \mathrm{ml}$ to $1.0 \mathrm{ml}$ of the working standard ascorbic solution corresponding to $10 \mu \mathrm{g}$ to $50 \mu \mathrm{g}$ values. Then take $1.0 \mathrm{ml}$ of the extracts in another test tube. The volume of all the test tubes is made up to $3 \mathrm{ml}$ with distilled water. $3 \mathrm{ml}$ of distilled water is taken in a blank. $1 \mathrm{ml}$ sodium phosphate and $1 \mathrm{ml}$ of ammonium molybdate and $1 \mathrm{ml}$ of sulfuric acid was added to all the test tubes. The blue colour was developed immediately read at $540 \mathrm{~nm}$. The amount of total antioxidant is expressed as $\mathrm{mg} / \mathrm{g}$ of fresh weight

\subsection{Test for ellagic acid}

Procedure 1: A 5g portion of homogenized fruit was weighted into a Rotary vapor flask and $5 \mathrm{ml}$ of water containing $80 \mathrm{mg}$ of ascorbic acid, $20 \mathrm{ml}$ of methanol, and $5 \mathrm{ml}$ of concentrated HCL was added. The mixture was refluxed for 5 hours at $90^{\circ} \mathrm{C}$.

$>$ Procedure 2: The extraction of phenolic compound was carried out with three subsequent extractions with 15ml of methanol/HCL $0.01 \mathrm{~N}$ (9:1) on 10g of homogenized fruits. Seeds and skin are not separated, whereas elderberry stalks were removed. Each time, after acidified methanol addition, the sample was vortexes for $2 \mathrm{~min}$ and then centrifuged at $3500 \mathrm{~g}$ for $10 \mathrm{~min}$ at $10^{\circ} \mathrm{C}$.

Flavones were detected an aglycones after acidic hydrolysis, performed according to the method applied by ageel et al. On Vitis venifera fruit extract, but reducing the volume of the reaction mixture. Precisely, 100microml of methanol extract were diluted with 200 microml of water and $50 \mathrm{ml}$ of 1.7 M HCL and vortexes for $2 \mathrm{~min}$. tubes were then placed in a boiling water bath for $30 \mathrm{~min}$ and allowed to react. Once the hydrolysis was completed, the sample was cooled under running water and $150 \mathrm{ml}$ of MEOH was added, in order to obtain a final volume of 500 microml of the hydrolyze. Finally, the presence of pink colour indicates the presence of Ellagic acid.

\section{RESULT AND DISCUSSION}

In the present study, evaluates the phytochemicals, biochemical analysis and achieve the antibacterial and antioxidant activity of the Vitis venifera.

\subsection{Phytochemical screening of Vitis venifera fruit}

In this study, the phytochemical constituents like carbohydrates, protein, amino acids, alkaloids, tannins, phenol and terpenoids were analyzed. The above phytochemical constituents were highly present in the ethanol, acetone and aqueous extracts Vitis vinifera fruit sample. This was shown in the table 3.1 .

Previous studies reported and vitis vinifera fruitcontains alkaloid, flavonoid, saponins, triterpenes in ethanol and aqueous extract (Wael Abdel-Mageed et al 2013) fruits contains sterols, phenolic compounds and fixed fats in ethanol extract (Atul Kabra et al 2013) 


\section{International Journal of Current Science Research and Review}

ISSN: 2581-8341

Volume 03 Issue 08 August 2020

DOI: 10.47191/ijcsrr/V3-i08-02, Impact Factor: 6.595

IJCSRR@ 2020

www.ijcsrr.org

Table 3.1: Phytochemical screening of Vitis venifera fruit

\begin{tabular}{|c|c|c|c|}
\hline Tests & Ethanol & Acetone & Aqueous \\
\hline $\begin{array}{l}\text { Alkaloid } \\
\text { 1. Wager's Test } \\
\text { 2. Dragendorff's Test } \\
\text { 3. Mayer' Test }\end{array}$ & $\begin{array}{l}+ \\
+ \\
+\end{array}$ & $\begin{array}{l}+ \\
+ \\
+\end{array}$ & $\begin{array}{l}+ \\
+ \\
+\end{array}$ \\
\hline $\begin{array}{l}\text { Amino Acid } \\
\text { Ninhydrin Test }\end{array}$ & + & + & + \\
\hline $\begin{array}{l}\text { Carbohydrates } \\
\text { 1. Molish'Test } \\
\text { 2. Benedict's Test }\end{array}$ & $\begin{array}{l}+ \\
+\end{array}$ & $\begin{array}{l}+ \\
+\end{array}$ & $\begin{array}{l}+ \\
+\end{array}$ \\
\hline $\begin{array}{l}\text { Fixed Oils and Fats } \\
\text { 1. Spot Test } \\
\text { 2.Saponification Test }\end{array}$ & $\begin{array}{l}- \\
-\end{array}$ & $\begin{array}{l}- \\
-\end{array}$ & - \\
\hline $\begin{array}{l}\text { Tannin } \\
\text { Ferric Chloride Test }\end{array}$ & + & + & + \\
\hline $\begin{array}{l}\text { Phenol } \\
\text { 1.Ferric chloride Test } \\
\text { 2. Lead Acetate Test }\end{array}$ & $\begin{array}{l}+ \\
+\end{array}$ & $\begin{array}{l}+ \\
+\end{array}$ & $\begin{array}{l}+ \\
+\end{array}$ \\
\hline $\begin{array}{l}\text { Phyto sterols } \\
\text { 1. Libermann Test } \\
\text { 2. Burchard's Test }\end{array}$ & $\begin{array}{l}+ \\
+\end{array}$ & $\begin{array}{l}+ \\
+\end{array}$ & $\begin{array}{l}+ \\
+\end{array}$ \\
\hline $\begin{array}{l}\text { Protein } \\
\text { 1. Million's Test } \\
\text { 2. Biuret's Test }\end{array}$ & $\begin{array}{l}+ \\
+\end{array}$ & $\begin{array}{l}+ \\
+\end{array}$ & $\begin{array}{l}+ \\
+\end{array}$ \\
\hline Saponins & - & - & - \\
\hline
\end{tabular}

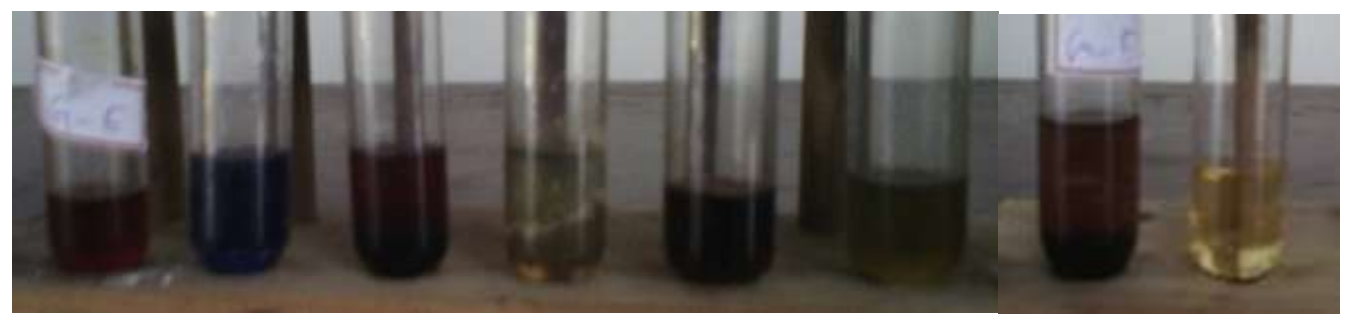

Figure 3.1: Ethanol extract of Vitis venifera

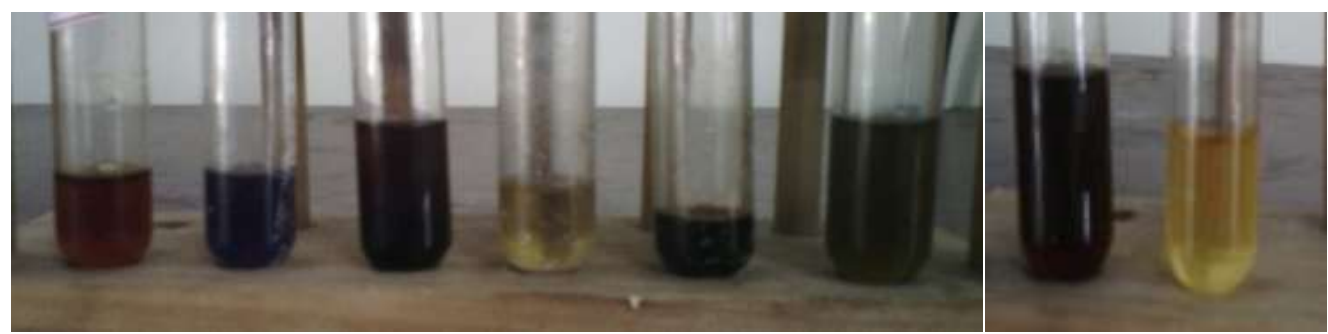

Figure 3.2: Acetone extract of Vitis venifera 


\section{International Journal of Current Science Research and Review}

ISSN: 2581-8341

Volume 03 Issue 08 August 2020

DOI: 10.47191/ijesrr/V3-i08-02, Impact Factor: 6.595

IJCSRR@ 2020

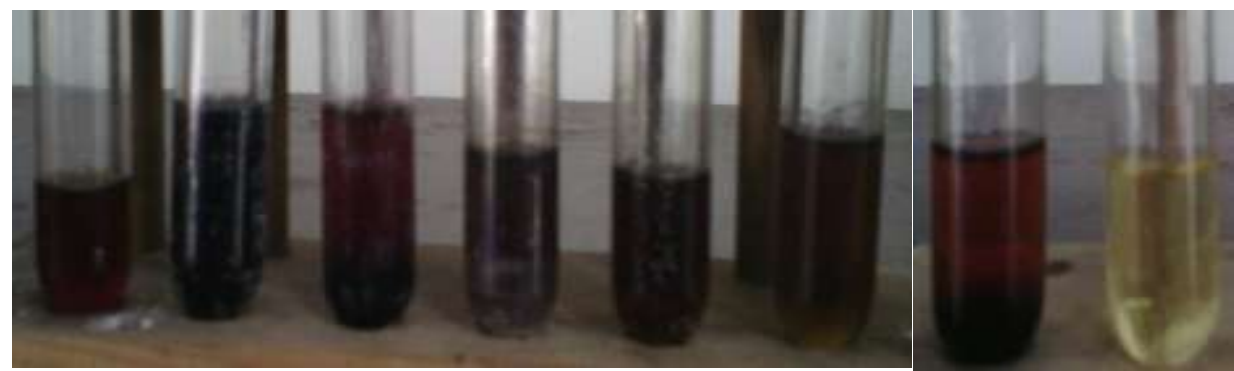

Figure 3.3: Aqueous extract of Vitis venifera

\subsection{Ash \& Moisture content of Vitis venifera}

The present study showed that the moisture and ash content of Vitis venifera fruit represented as in \%, this was shown in the following Table.

Table 3.2: Moisture and Ash content of Vitis venifera fruit

\begin{tabular}{|l|l|l|}
\hline S. No & Moisture \& Ash & $\begin{array}{l}\text { Percentage of } \\
\text { Moisture \& Ash }\end{array}$ \\
\hline 1 & Moisture & $51.09 \%$ \\
\hline 2 & Ash & $8.74 \%$ \\
\hline
\end{tabular}

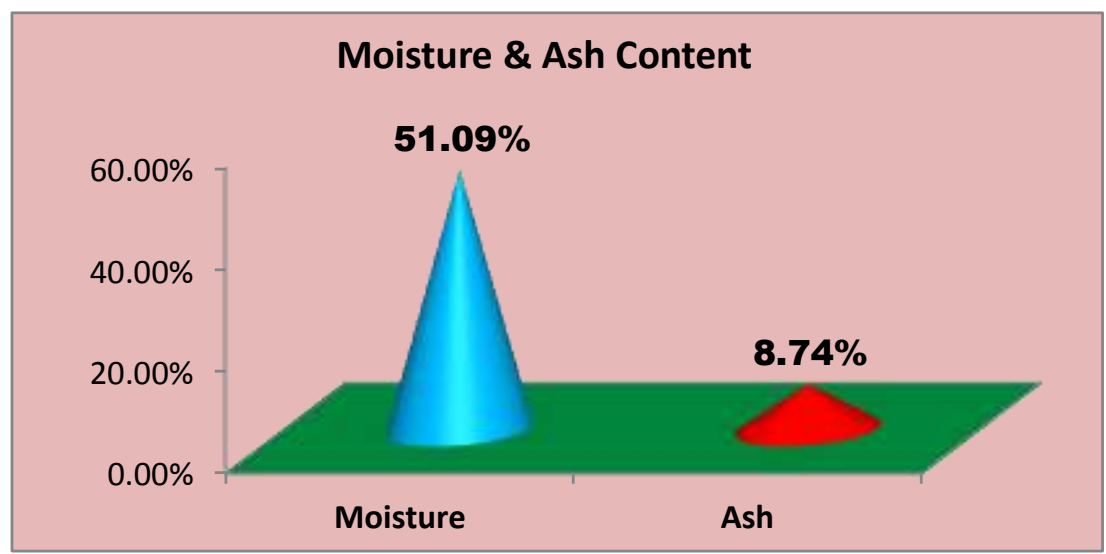

Grape 3.1: Comparison of Moisture and Ash content of Vitis vinifera

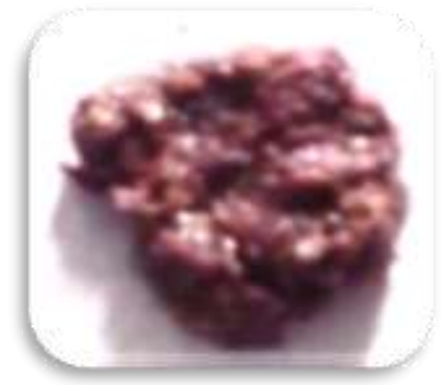

Figure 3.4: Moisture Content of vitis vinifera

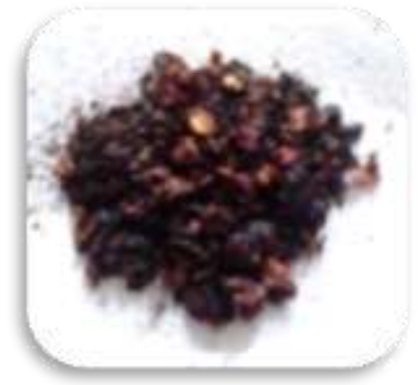

Figure 3.5: Ash Content of vitis vinifera

Previous studies reported the values of ash and moisture content as \% of rosacea and vitaceae species (Mounior et al 2013). 


\section{International Journal of Current Science Research and Review}

ISSN: 2581-8341

Volume 03 Issue 08 August 2020

DOI: 10.47191/ijcsrr/V3-i08-02, Impact Factor: 6.595

IJCSRR@ 2020

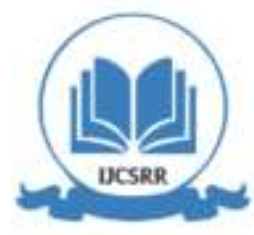

www.ijcsrr.org

\subsection{Biochemical constituents of Vitis venifera}

In this study, the biochemical constituents like Protein, Magnesium and Phosphorous were analyzed. The above biochemical constituents were considerably present in the ethanol, acetone and aqueous extracts of Vitis venifera fruit sample. The amount of those constituents present in the fruits as follows,

Table 3.3: Various biochemical constituents in grape fruit

\begin{tabular}{|l|l|l|l|}
\hline \multirow{2}{*}{ Constituents } & \multicolumn{4}{|l|}{ Extracts of Vitis venifera } \\
\cline { 2 - 4 } & Acetone & Ethanol & Aqueous \\
\hline Protein & $3.9 \mathrm{mg}$ & $6.0 \mathrm{mg}$ & $3.5 \mathrm{mg}$ \\
\hline Phosphorous & $9.6 \mathrm{mg}$ & $6.0 \mathrm{mg}$ & $6.0 \mathrm{mg}$ \\
\hline Magnesium & $10.5 \mathrm{mg}$ & $20.0 \mathrm{mg}$ & $20.0 \mathrm{mg}$ \\
\hline
\end{tabular}

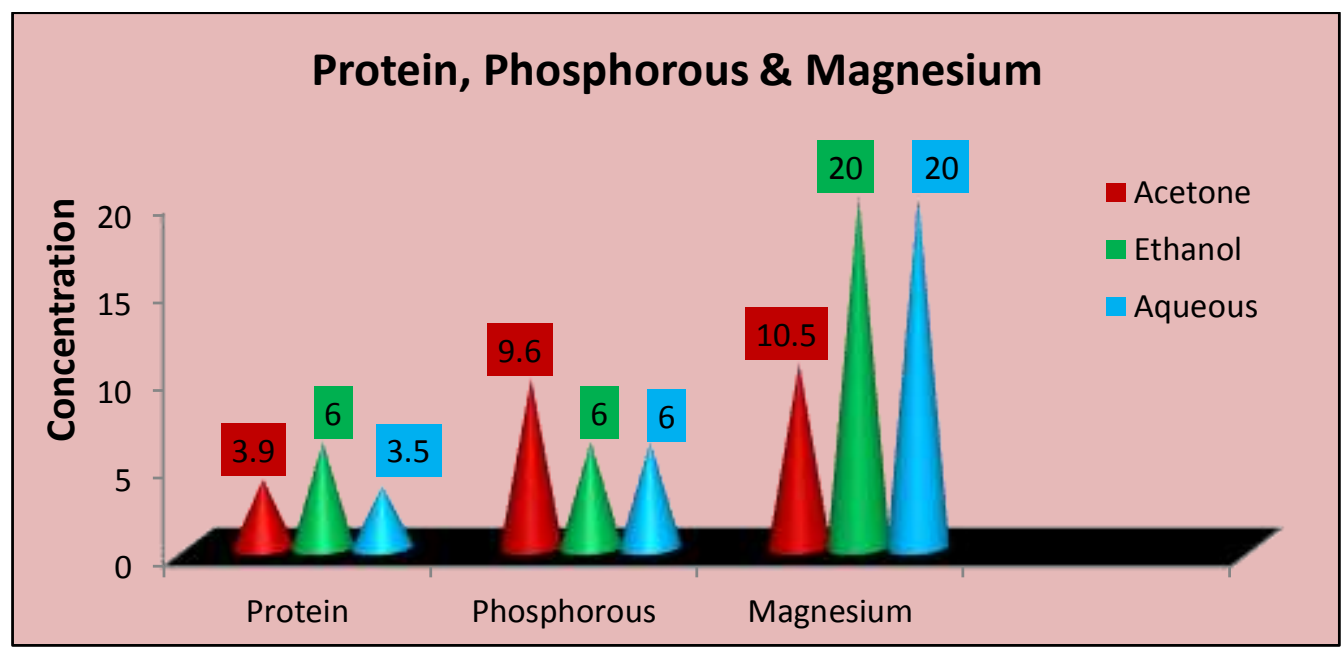

Graph 3.2: Biochemical parameters of Grape extract

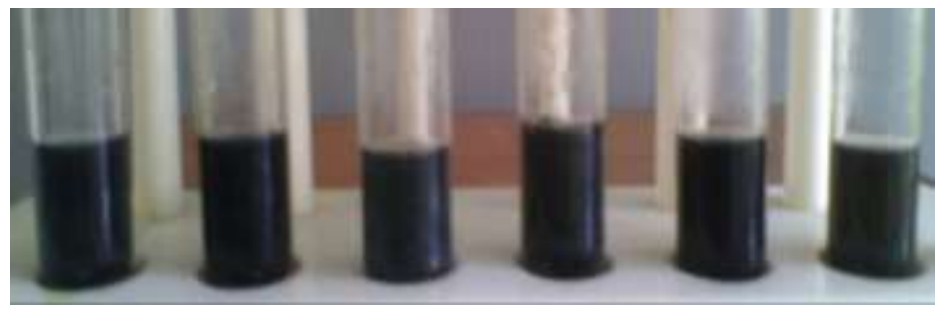

Figure 3.6: Protein content in Acetone, Ethanol and Aqueous extract of Grape

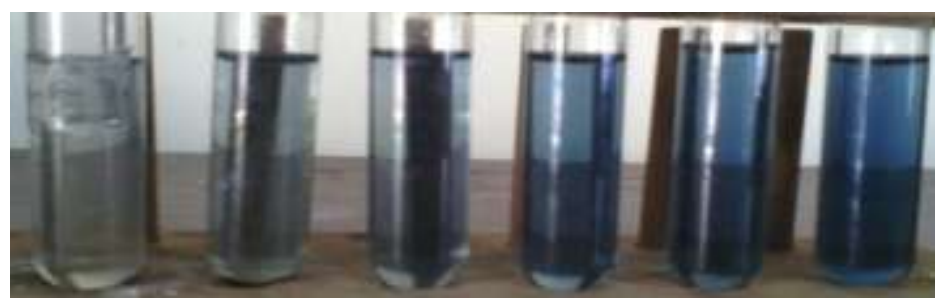

Figure 3.7: Phosphorous content in Acetone, Ethanol and Aqueous extract of Grape 


\section{International Journal of Current Science Research and Review}

ISSN: 2581-8341

Volume 03 Issue 08 August 2020

DOI: 10.47191/ijesrr/V3-i08-02, Impact Factor: 6.595

IJCSRR@ 2020

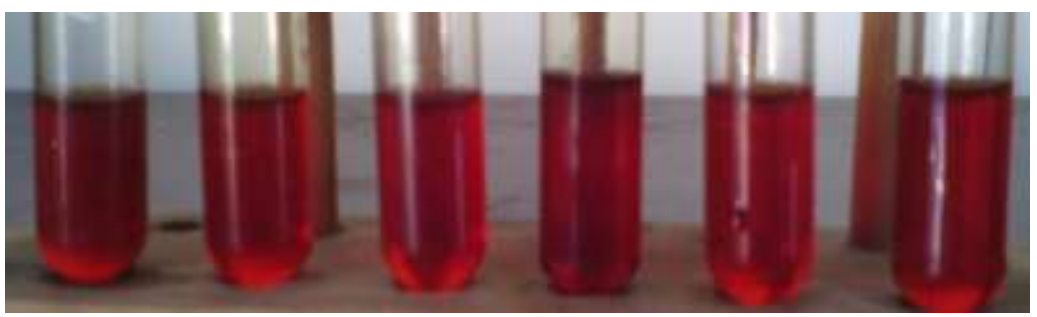

Figure 3.8: Magnesium content in Acetone, Ethanol and Aqueous extract of Grape

Previous studies reported the Vitis venifera fruit contains carbohydrates, protein, total sugar and lipids in ethanol and aqueous extract (Wael Abdel-Mageed et al 2013) and studies vitis venifera fruit contains carbohydrates, protein in ethanol extract (Atul Kabra et al 2013).

\subsection{Separation of Amino Acids by ascending paper chromatography in vitis venifera}

In this study, the Aromatic amino acid like aspartic acid and glycine were analyzed. The above Aromatic amino acids were highly present.

Table: 3.4: Rf values of Standard Amino acids and Amino acid in Vitis venifera

\begin{tabular}{|l|l|l|l|}
\hline Amino Acid & $\begin{array}{l}\text { Distance travelled by } \\
\text { the solute }(\mathbf{c m})\end{array}$ & $\begin{array}{l}\text { Distance travelled by the } \\
\text { solvent }(\mathbf{c m})\end{array}$ & Rf value \\
\hline A & 0.7 & 7.0 & 0.1 \\
\hline B & 0.9 & 7.0 & 0.12 \\
\hline Unknown & 0.9 & 7.0 & 0.12 \\
\hline
\end{tabular}

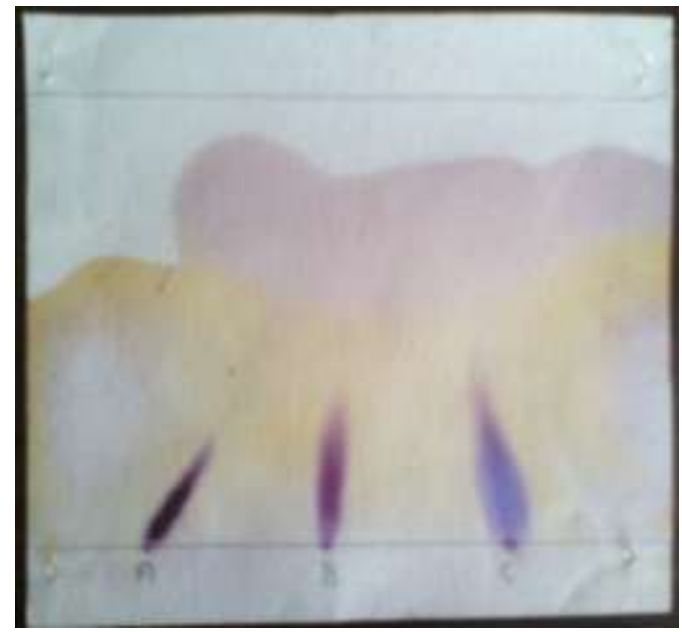

Figure 3.9: Chromatogram indicates the presence of Amino acid in Vitis vinifera sample

The Rf value of unknown Amino acid is close to that of sample B, so as we conclude the Amino acid present in Vitis vinifera is an Glycine. Previous studies reported the vitis venifera contains Linoleic acid, 2,5-Octadecadiynoic acid separated by Gas chromatography/mass spectroscopy (Sherif H. Abd-Alrahman et al 2013).

\subsection{Antibacterial Activity of Vitis venifera}

The extracts of Vitis venifera (fruit) had been tested for their antibacterial activities and an interesting antibacterial profile has been observed against E. coli and Enterococcus sps by Gel diffusion method. The extracts showed enormous activity against 2 bacteria tested. The activities of extracts are mentioned in the terms of zones of inhibitions ( $\mathrm{mm}$ ). 


\section{International Journal of Current Science Research and Review}

ISSN: 2581-8341

Volume 03 Issue 08 August 2020

DOI: 10.47191/ijesrr/V3-i08-02, Impact Factor: 6.595

IJCSRR@ 2020

www.ijcsrr.org

Table: 3.5: Level of antibacterial Activity of Vitis venifera extracts

\begin{tabular}{|l|l|l|l|}
\hline \multirow{2}{*}{$\begin{array}{l}\text { S. } \\
\text { No }\end{array}$} & \multirow{2}{*}{ Extracts } & \multicolumn{3}{|l|}{ Zone of Inhibition $(\mathbf{m m}$ in diameter $)$} \\
\cline { 3 - 4 } & & Enterococcus. Sp. & E.coli sp. \\
\hline 1 & Ethanol & $0.3 \pm 0.2$ & $0.3 \pm 0.2$ \\
\hline 2 & Acetone & $0.1 \pm 0.3$ & $0.1 \pm 0.1$ \\
\hline 3 & Aqueous & $0.4 \pm 0.1$ & $0.2 \pm 0.1$ \\
\hline
\end{tabular}

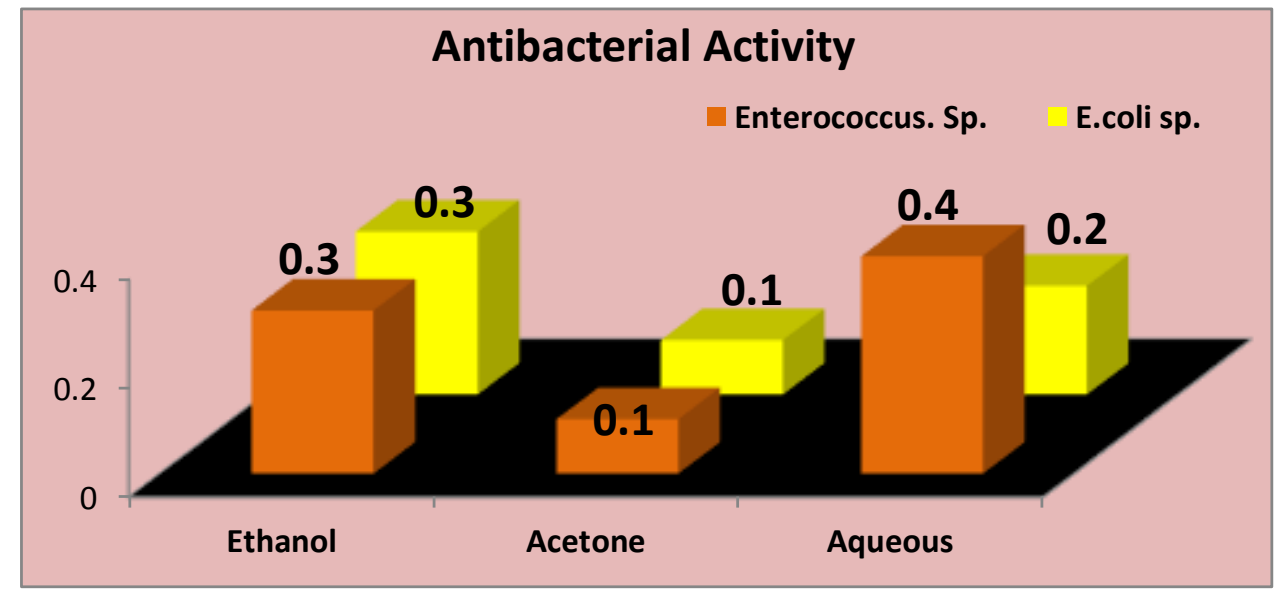

Graph 3.3: Antibacterial Activity of Vitis venifera extracts

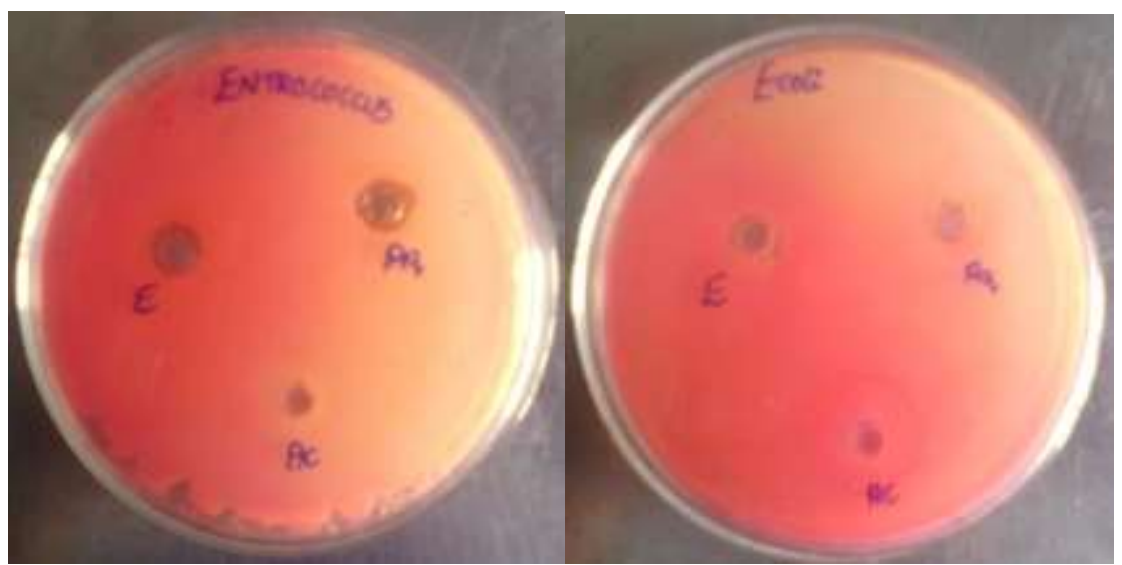

Figure 3.10: Shows the Antibacterial activity of Vitis vinifera extracts

From the result, we observed that the zone of inhibition of Enterococcus sps is higher in aqueous extract whereas the zone of inhibition of Escherichia coli is Ethanolic extract than others.

\subsection{Total Antioxidant Capacity of Vitis vinifera}

In this study, the Total antioxidant capacity was analyzed. The antioxidant capacity was highly present in the acetone extract of Vitis vinifera fruit sample. 


\section{International Journal of Current Science Research and Review}

ISSN: 2581-8341

Volume 03 Issue 08 August 2020

DOI: 10.47191/ijesrr/V3-i08-02, Impact Factor: 6.595

IJCSRR@ 2020

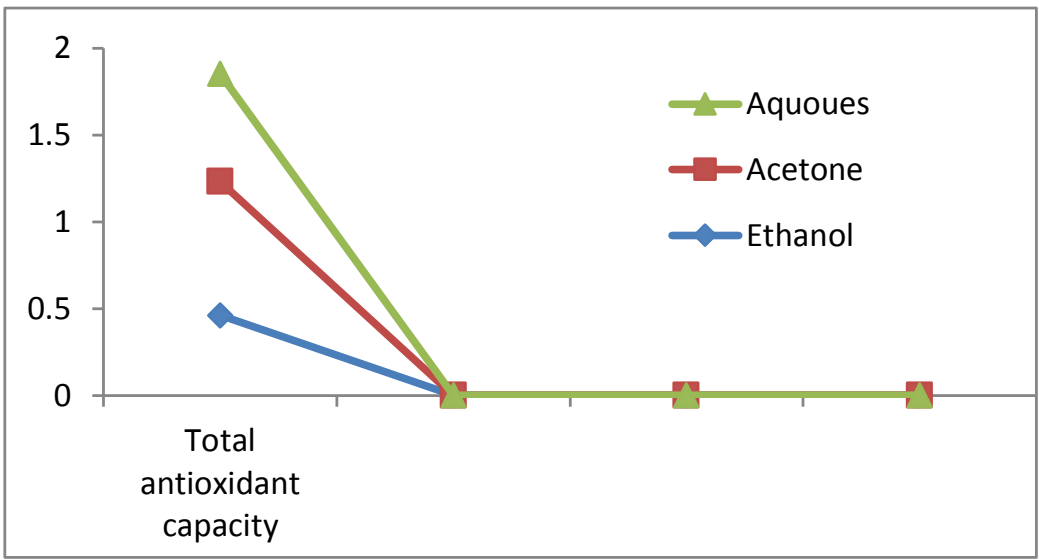

Graph 3.4: Total Antioxidant Capacity of Vitis vinifera

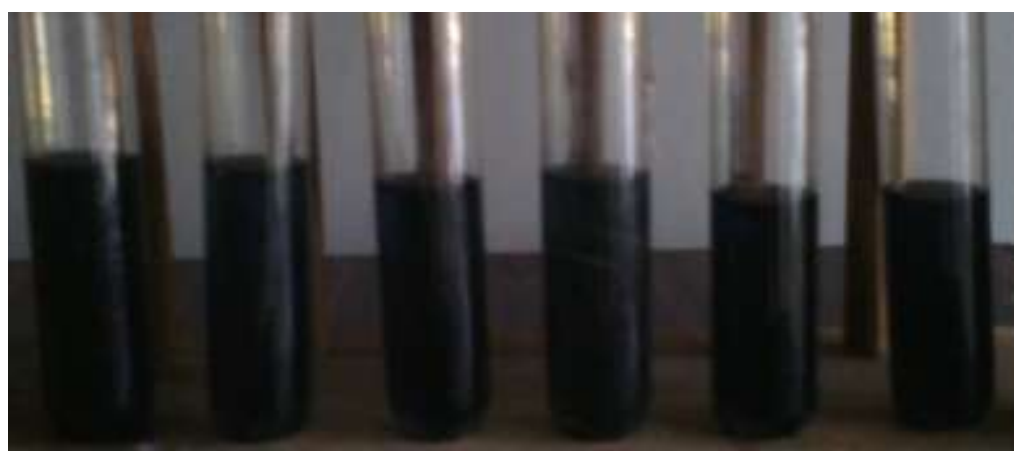

Figure 3.11: Total antioxidant capacity of different extracts of Vitis vinifera

\subsection{Identification of Ellagic acid in Vitis vinifera}

The identification of Ellagic acid in the grape fruit is the formation of pink colour in the reaction mixture. This is confirmed by the same procedure is done in banana also. But there is no any colour change in the banana sample so the Ellagic acid is absent.

Procedure 1:

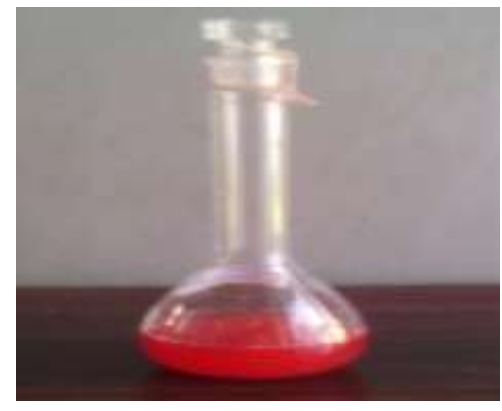

Figure 3.12 \& 3.13: Presence of Ellagic acid in Vitis vinifera

Procedure 2:
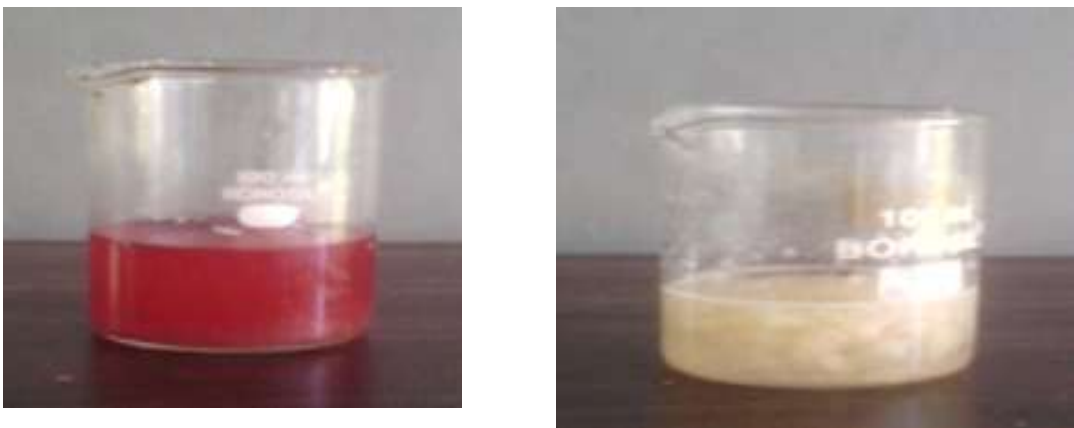

Figure 3.14 : Absence of Ellagic acid in Banana

\section{CONCLUSION}

Different solvent extract namely ethanol, acetone, aqueous extract were prepared from vitis vinifera fruit and screened for its phytoconstituents. The Aqueous and Acetone extract was found to be the best source of various phytochemicals (Proteins and Amino acids) when compared with other solvent extracts. Bio-macromolecules like protein, phosphorous and magnesium were 


\section{International Journal of Current Science Research and Review}

ISSN: 2581-8341

Volume 03 Issue 08 August 2020

DOI: 10.47191/ijcsrr/V3-i08-02, Impact Factor: 6.595

IJCSRR@ 2020

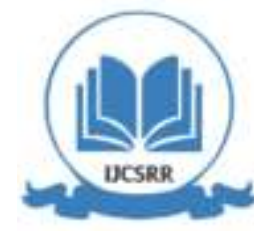

www.ijcsrr.org

estimated quantitatively. This study confirmed the medicinal importance of vitis vinifera fruits. All the extracts of Vitis vinifera have antibacterial activity against selected microorganisms. It is expected that using natural products as therapeutic agents will probably not elicit resistance in microorganisms.

This study has confirmed that the antibacterial activity of Vitis vinifera fruits extract against certain microorganisms. Results of this study showed that have found for that ethanol, acetone, aqueous extract of vitis vinifera fruit sample was quite adequate inhibiting the growth of E.coli and Enterococcus. This study also evaluated the Total antioxidant capacity of Vitis vinifera fruit extracts. Result of this showed that have high level of antioxidant capacity in aqueous extract.

From this study we identified the Ellagic acid in Vitis vinifera. Ellagic acid is a natural phenol antioxidant found in numerous fruits and vegetables. The anti-proliferative and antioxidant properties of ellagic acid have prompted research into its potential health benefits. So the consumption of grape leads to prevent many diseases like cancer because they have Ellagic acid which possesses the antioxidant, anti-mutagen and anti-cancer properties.

\section{BIBLIOGRAPHY}

1. Agustin ET (2007). Dayaantibakteriekstrakbuahmakutadewa (Phaleriamacrocarpa (Scheff) Boerl) terhadapbakteri Streptococcus alpha haemolyticus: penelitianlaboratoris. Bachelor Thesis.UniversitasAirlangga, Surabaya

2. Ali, Y. M., Iqbal, S. Z. A. Shah, and M. J. Ahmed. 2003. Effect of different combinations of nitrogen, phosphorous and farm yard manure on yield and quality of strawberry. Sarhad J. Agric. 19: 185-188

3. Ames,B.N.,M.K.Shigena, and T.M. Hagen.1993.Oxidants, antioxidants and the degenerative diseases of aging.Proc.natl.Acad.Sci.U.S.A.90;7915-7922

4. Anastasiadi M, Chorianopoulos NG, Nychas GJ, Haroutounian SA. Antilisterial activities of polyphenolrich extracts of grapes and vinification byproducts. J Agric Food Chem. 2009;57(2):457-63

5. Aravindaram K \&Yang NS, 2010. “Anti-inflammatory plant natural products for cancer therapy", Plantamedica, vol :76(11), pg : 1103-1117. Doi:10.1055/ s-0030-1249859

6. A.R. Törrönen, Identification and quantification of phenolic compounds in berries of Fragaria and Rubus species (Family Rosaceae), J. Agric. Food Chem. 52 (2004) 6178-6187

7. Bagchi D, Bagchi M, Stohssj, Das D k, Ray CA, et.al(2000) Free radicals and grape fruit proanthocyanidin extract; importance in human health and disease prevention J. Toxicol 148.187-197

8. 8] Brooks JT, Bergmire-Sweat D, Kennedy M, Hendricks K, Garcia M, Marengo L, Wells J, Ying M, Bibb W, Griffin PM, Hoekstra RM, Friedman CR (2004). Outbreak of Shiga toxin-producing Escherichia coli O111:H8 infections among attendees of a high school cheerleading camp. Clin Infect Dis 38, 190-198

9. D. Iveković, S. Milardović, M. Roboz, B. S. Grabarić, The Analyst 130 (2005) 708

10. F. A. Tomas-Barberan, M. N. Clifford, J. Sci. Food Agric. 80 (2000) 1024

11. Gupta SS. Prospects and Perspectives of Natural Plant Products In Medicine. Indian Journal of Pharmacol. 1994; 26:1-12

12. grosvenor et al 1995; ratnakar and murthy 1995; silva et al 1996; David 1997; saxena 1997; nimri et al 1999; saxena and sharma 1999).

13. Hausteen B. Flavonoids, a class of natural products of high pharmacological potency. Biochem Pharm. 1983; 32:11411148

14. Häkkinen, S.H. and A.R. Törrönen. 2000. Content of flavonols and selected phenolic acids in strawberries and Vaccinium species: Influence of cultivar, cultivation site and technique. Food Res. Intl. 33:517-524

15. Indian Horticulture Database. 2014. Ministry of Agriculture, Government of India, Gurgoan. Website: www.nhb.gov.in. 3307 Vijay Kumar, M. Pal, R.S. Singh, A.P. Singh, M.D. Ojha, R.K. Verma, R.B. Verma and P.K. Singh

16. Kammerer D, Claus A, Carle R and Schieber A. Phenolic screening of pomace from red and white grape varieties (Vitis vinifera L.) By HPLC-DAD-MS/ MS. J Agric Food Chem 2004; 52:4360-4367. 7. Rodriguez MR, Peces RR, Vozmediano CJL, Gascuena MJ and Romero GE. Phenolic compounds

17. Lee S, San D, Ryu J, Lee YS, Jung SH, Kang J. Antioxidant activities of Acanthopanaxsenticosus stems and their lignin components. Arch Pharm Res. 2004;27:10610 


\section{International Journal of Current Science Research and Review}

ISSN: 2581-8341

Volume 03 Issue 08 August 2020

DOI: 10.47191/ijcsrr/V3-i08-02, Impact Factor: 6.595

IJCSRR@ 2020

Www.ijcsrr.org

18. Li H, Wang Z, Liu Y. Review in the studies on tannins activity of cancer prevention and anticancer. Zhongyao-Cai. 2003; 26(6):444-448

19. Li H, Wang X Li P, Li Y, Wang H (2008) Comparative study of antioxidant activity of grape (Vitis vinifera) Assessed different method.J food drug analysis1-7

20. M. Kopjar, D. Šubarić, V. Pližota, Glukozinolati: Biodostupnost i utjecajnazdravljeljudi, J. Hum. Nutr.Diet. 1 (2012) $22-$ 35. [2] K.R. Määttä-Riihinen, A. Kamal-Eldin

21. M. N. Clifford, A. Scalbert, J. Sci. Food Agric. 80 (2000) 1118

22. Ricardo da Silva JM. Monomeric, oligomeric, and polymeric flavan-3-ol composition of wines and grapes from Vitis vinifera L. Cv

23. singliton VL, Tannins and the qualities of wines ,in laks P.E. and Hemingway, R.W. (eds) Plant Polyphenols. Plenum Press, New York, NY; 1992.P.859-880.:6475-6481

24. Tsao R, Deng Z. Seperation procedures for naturally occurring antioxidant phytochemicals. Chromatogr B. 2004; 12:8599

25. United States Department of Agriculture (nd). US Strawberry Industry. Available from http://usda.mannlib.cornell.edu/mannusda/viewdocumentinfo.do Documentid=1381. Accessed Juni 3, 2011

26. vennila S ,bupeshg,mathiyazhagank, baskerm, Amutha S ,et al. (2012) Qualitative photochemical Screening and In vitro antioxidant activity of Hisora,advanced biotech journal 14:3-20

27. Y. Amakura, M. Okada, S. Tsuji, Y. Tonogai, J. Chromatogr. A 896 (2000) 87

28. Serra AT,Matias A, nunesVM,LeitaoMC,Brito D, et.alinVitro Evaluation of Olive and Grape-Based Natural Extracts as Potential Preservatives for Food. Innovative Food Science And emerging technologies9(3):311-319 